\title{
Analysis of PER, DER, and ROA on the Textile Companies' Performance Listed on Indonesian Stock Exchange
}

\author{
Fathonah Eka Susanti ${ }^{1}$, Titi Laras ${ }^{2}$ \\ 1,2 Management Department, Faculty of Economics and Business, \\ Universitas Janabadra Yogyakarta
}

fathonah@janabadra.ac.id

\begin{abstract}
Securities trading is a way to attract public funds in this case investors to develop an economy where the fund is the capital that the company needs to expand its business. The purpose of this study is to analyze the effect of price earning ratio, debt to equity ratio, and return on assets, simultaneously and partially significant on the stock price of textile companies for the period 2005-2012. This study used multiple regression test. The samples observed were textile industry subsectors on the Indonesian Stock Exchange from 2005-2012. Variables used price to earning ratio, debt to equity ratio, and ratio on asset as independent variables and stock prices as dependent variables. The results of this study prove that price earning ratio, debt to equity ratio, and return on assets are simultaneously and partially significant to the stock price of textile companies on the Indonesian Stock Exchange in 2005-2012.

Keywords: Price to Earning Ratio, Return on Asset, Debt to Equity Ratio, stock price, textile companies
\end{abstract}

JEL $\quad:$ M21

DOI : : 10.24002/kinerja.v25i1.4356

Received : 01/25/2021 Reviewed: 02/11/2021 Final Version: 3/09/2021

\section{INTRODUCTION}

Accompanied by the important role of the Indonesian Stock Exchange (IDX), the textile and garment industry are one of the industrial sectors that has gone public on the IDX which has had a significant impact on the Indonesian economy. This industry in Indonesia has quite good development potential and opportunities. This is supported by the ability of the textile industry to contribute to earning foreign exchange and at the same time absorbing labour. After the global crisis in 2008 , most of the textile and garment industries experienced a downward trend in net income. The crisis certainly had a profound impact on the company's performance in the years following the crisis. Investors will return to this industry if the company's performance is good. Company performance can be measured in various ways. One way to measure company performance is by using financial ratios. Types of financial ratios that are often used in assessing company 
performance are liquidity ratios, activity ratios, leverage ratios, profitability ratios and market ratios. The rush of foreign-made textile products flooded the market in Indonesia, especially textile products made in China. The flood of textile products from China has made domestic producers frenetic. This concern is based on the fact that the price of their products is far below the price of domestic textiles and in terms of quality it is no less good. Companies must have a competitive advantage in order to be able to compete and survive.

Angrawit (2009) states that Earning Per Share (EPS), Return on Assets (ROA), Price Earning Ratio (PER), Debt to Equity Ratio (DER) and Return on Equity have a significant effect on stock prices while Financial Leverage (FL) and Current Ratio (CR) has no significant effect on stock prices. The results of Pasaribu (2008) show that all fundamental factors and market ratios have a significant effect simultaneously and partially on stock prices in all industries. Earning Per Share (EPS) is a variable that has a dominant influence on six industries, profitability in the agricultural sector, liquidity in the property and real estate sectors on the Indonesia Stock Exchange (BEI) 2003-2006 period. Deitiana (2014) suggests that profitability affects stock prices. Liquidity, dividends, and sales growth have no effect on stock prices in the sample companies LQ45.

\section{LITERATURE REVIEW}

The share price is the market value of a share of a company or an issuer at a certain time which occurs on the stock market at a certain time and the share price is determined by market players (Hartono, 2011:143). The high and low of the stock price is determined by supply and demand. The stock price is used as a measure to assess the performance of the board of directors of a public company. The development of stock prices on the stock exchange is an interesting object for analysts to predict and analyze. Success in predicting the development of a company's stock price is the goal expected by investors who play in the capital market, especially investors who act as speculators. The factors that affect stock prices are fundamental, technical, and technical driving factors capital (Tandelilin, 2010).

One indicator of the market valuation ratio is the Price to Earning Ratio (PER) which can affect stock prices. PER is an indicator that investors use every day to assess market value. PER shows how much investors are willing to pay per currency unit of the reported profit and this is what makes this instrument quite important. Most financial managers think it is good if the shares of a company are sold at a high PER rate, because a high PER reflects that investors think the company has relatively safe income. The use of Price Earning Ratio (PER) is to indicate the number of currencies that must be paid by investors to obtain one rupiah of company earnings.

Debt to Equity Ratio is a ratio used to assess debt to equity, which is a balance between debt owned by a company and its own capital. This ratio serves to measure the extent to which owner's capital can cover debts to outsiders. For creditors, the greater this ratio, the less profitable it is, because the company suffered from greater the risk.

Return on assets (ROA) is used to measure the effectiveness of the company in generating profits by utilizing its assets. The higher the ROA, the higher the rate of return, the better of the performance. Return on Asset is used to evaluate 
whether top management gets an adequate return from the assets under control. This ratio is a useful measure if one wants to evaluate how well the company has used its funds. Therefore, ROA is often used by top management to evaluate business units in multinational companies.

\subsection{Hypothesis Development}

\subsubsection{Effect of Price Earning Ratio (PER) on stock prices}

$P E R$ is a ratio that shows the ratio between the price of shares in the primary market offered compared to the income received. This measure involves an amount that cannot be controlled directly by the company, so that this ratio is the best indicator for investors to estimate the company's future performance, market price indicates the shareholder's estimate of future returns. PER also has an effect directly to the stock price. PER information indicates the amount of currency that must be paid by investors to obtain one currency of company earnings (Tandelilin, 2010:375). Deitiana (2014) suggests that profitability affects the stock prices. Liquidity, dividends, and sales growth have no effect on stock prices in the sample companies LQ-45. Luthfi (2013) states that simultaneously EPS, PER, ROA, DER, and MVA have a significant effect on stock prices. Based on the theory and research results, it shows that there is a relationship between price earning ratio and stock prices.

$\mathrm{H} 1$ : Price Earning Ratio has a positive effect on stock prices of manufacturing companies in the textile industry subsector.

\subsubsection{Effect of Debt To Equity Ratio (DER) on stock prices}

DER is a comparison between loan or debt funds compared to capital in an effort to develop a company. This ratio shows the ratio between loan or debt funds and capital in the company's development efforts. The higher the DER, the greater the risk faced, and investors will ask for a higher rate of return (Sartono, 2010). Sondakh, Tommy, and Mangantar (2015) suggest that CR, DER, ROA, and ROE simultaneously influence stock prices. Based on the theory and research results, it shows that there is a relationship between the debt-to-equity ratio and the stock price.

H2: Debt to equity ratio has a positive effect on stock prices of manufacturing companies in the textile industry subsector.

\subsubsection{Effect of Return On Assets (ROA) on stock prices}

$\mathrm{ROA}$ is a ratio that measures company's ability to generate net income based on a certain level of assets. From an investor's point of view, one of the important indicators to assess the company's prospects in the future is to see the extent to which the company's profitability has grown. The higher this ratio, the better the condition of the company and shows that the company is more effective in utilizing assets to generate net profit after tax. Shareholders pay particular attention to the level of profit both now and in the future because this profit rate will affect the price of the shares they own (Lukman, 2011). Watung, llat (2016) stated that ROA, NPM, and EPS have a significant effect on stock prices. Based on the theory and research results, it shows that there is a relationship between return on assets and stock prices. 
H3: Return on assets has a positive effect on stock prices of manufacturing companies in the textile industry subsector.

\subsubsection{Price Earning Ratio (PER), Debt to Equity Ratio (DER), and Return on Assets (ROA) have a joint effect on stock prices of manufacturing companies in the textile industry subsector}

If PER, DER, and ROA increase, it indicates that the company has a high growth rate accompanied by a high level of ability to repay debts to other parties and is increasingly effective in utilizing assets to generate net profit after tax. This will attract investors to invest in the company. The high interest of investors in investing will cause stock prices to rise. This is supported by research by Pratama (2009) which states that simultaneously all financial ratios (DER, PBV, EPS, DPR, PER, ROA have an effect on stock prices). Novasari (2013) states that it has a significant effect on stock prices. Agustina and Hendratno (2019) suggests that simultaneously the current ratio, Debt to Asset Ratio, Debt to Equity Ratio, Return on Asset, and Price Earning Ratio have a significant effect on stock prices. Based on the theory and research results, it shows that there is a relationship between return on assets and stock prices.

H4: Price Earning Ratio (PER), Debt to Equity Ratio (DER), and Return on Assets (ROA) have a simultaneously effect on stock prices of manufacturing companies in the textile industry subsector.

Based on this description, a figure 1 of the research paradigm scheme appears as follows:

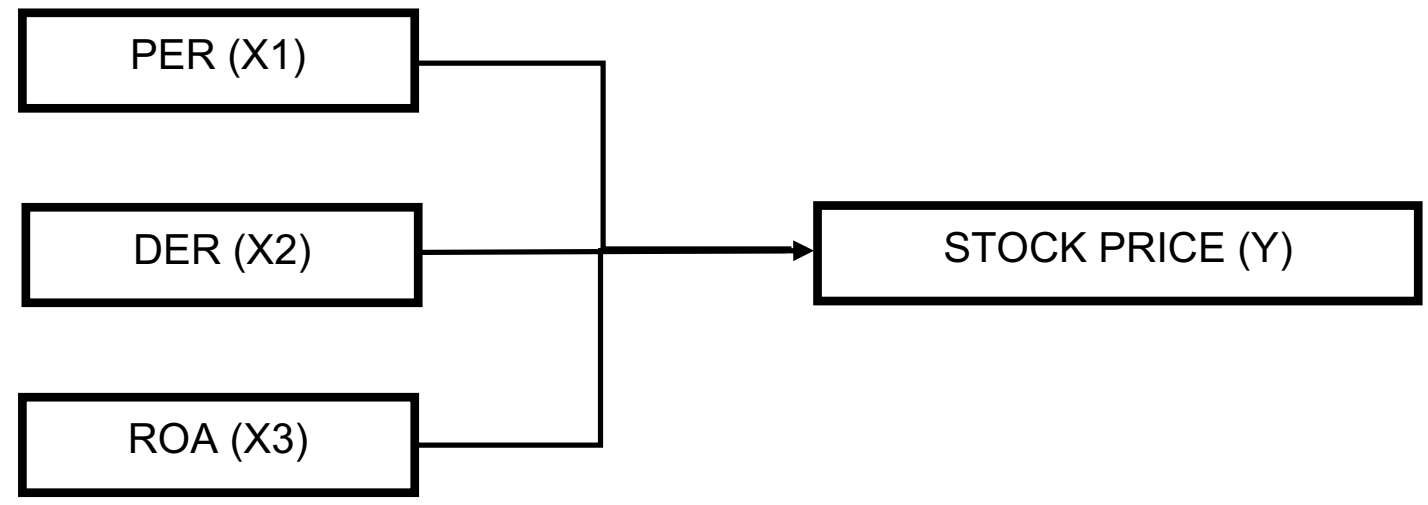

Figure 1. Research Paradigm Scheme

\section{RESEARCH METHOD}

The object of this research is textile industry sub-sector manufacturing company that listed on the Indonesian Stock Exchange for the period observed 2005-2012. The data source used is secondary data. Complete data collection related to this study was carried out by means of documentation through the IDX Corner of Janabadra University Yogyakarta and literature related to the problem under study. 
The independent variables in this study are price earning ratio (PER), debt to equity ratio (DER), and return on assets (ROA). While the dependent variable in this study is the stock price. This research is a confirmation research which aims to explain the casual relationship between variables through hypothesis testing. Where the data or variables are examined first then the relationship is explained. The method used is a descriptive method that uses tables and graphics and is quantitative in nature. In this study, the researcher used the purposive sampling method, which is a non-probability sampling method that takes objects with sampling criteria that have been determined in the textile industry subsector manufacturing companies listed on Indonesian Stock Exchange in 2005-2012.

\section{RESEARCH RESULT}

\subsection{Hypotheses Testing}

Hypothesis testing is done by analyzing the structural model relationships. Hypothesis data analysis can be seen from the standardized regression weight value which shows the coefficient of influence between variables in the following table:

Table 2. T-Test Coefficients

\begin{tabular}{|c|c|c|c|c|c|c|}
\hline \multirow[t]{2}{*}{ Moc } & & \multicolumn{2}{|c|}{$\begin{array}{l}\text { Unstandardized } \\
\text { Coefficients }\end{array}$} & \multirow{2}{*}{$\begin{array}{c}\text { Standardized } \\
\text { Coefficients } \\
\text { Beta } \\
\end{array}$} & \multirow[t]{2}{*}{$t$} & \multirow[t]{2}{*}{ Sig. } \\
\hline & & $\mathrm{B}$ & Std. Error & & & \\
\hline \multirow{4}{*}{1} & (Constant) & 12.705 & 9.159 & & 1.387 & 0.176 \\
\hline & PER (X1) & 0.130 & 0.213 & 0.083 & 0.612 & 0.024 \\
\hline & DER (X2) & 0.253 & 0.142 & 0.271 & 0.787 & 0.000 \\
\hline & ROA (X3) & 0.028 & 0.230 & 0.019 & 0.124 & 0.002 \\
\hline
\end{tabular}

Source: SPSS Data Processing

From the ANOVA or F-test, the significance value is 0.012 which is smaller than 0.05 , so the regression model can be used to predict or it can be said that the three independent variables simultaneously affect stock prices.

Table 1. F-test ANOVA

\begin{tabular}{llccccc}
\hline Model & & $\begin{array}{c}\text { Sum of } \\
\text { Squares }\end{array}$ & df & $\begin{array}{c}\text { Mean } \\
\text { Square }\end{array}$ & F & Sig. \\
\hline \multirow{3}{*}{1} & Regression & 11.007 & 10 & 1.101 & 2.901 & 0.012 \\
& Residual & 11.383 & 30 & 0.379 & & \\
& Total & 22.390 & 40 & & & \\
\hline
\end{tabular}

Notes:
a. Dependent Variable: stock price
b. Predictors: (Constant), PER (X1), DER (X2), ROA (X6)

Source: SPSS Data Processing 
The t-value of the PER regression coefficient is 0.612 with a probability value of 0.024 t-count is positive and the probability number is below 0.05 or $(0.024$ $<0.05)$, then the $\mathrm{H} 1$ is accepted. This means that PER has a positive effect on stock price. Each time there is an increase in PER, the share price also increases by the regression coefficient. The t-value of the DER regression coefficient is 0.787 with a probability value of 0.000 , $t$-count is positive, and the probability number is below 0.05 or $(0.000<0.05)$ then the $\mathrm{H} 2$ is accepted. This means that DER has a positive effect on stock prices. If there is an increase in DER, the share price will also increase by the regression coefficient. The $t$-value of the ROA regression coefficient is 0.124 with a probability value of 0.002 , the t-value is positive, and the probability number is below 0.05 or $(0.002<0.05)$, so the $\mathrm{H} 3$ is accepted. This means that ROA has a positive effect on stock prices. If there is an increase in ROA, the stock price will also increase by the regression coefficient. The ignificance value of F-test is 0.012 less than 0.05 , it can conclude that the regression model can be used to predict, or it can be said that the $\mathrm{H} 4$ is accepted. It means that Price Earning Ratio (PER), Debt to Equity Ratio (DER), and Return on Assets (ROA) together have an effect on stock prices.

\subsection{Discussion}

Based on the results of the hypothesis testing above, it is evident that the Price to Earning Ratio (PER) has a positive effect on stock prices, meaning that if the condition is constant, then any increase in PER will affect the increase in stock prices, on the other hand, if PER decreases, it will affect the decline in stock prices. This research is supported by previous research, Deitiana (2014) states that profitability has an effect on stock prices in the LQ45 sample company, Pasaribu (2008) with the results of research on Price Earning Ratio (PER) has a positive effect on stock prices, Kusumawardani (2009) with research results Price to Earning Ratio (PER) has a positive effect on stock prices.

Based on the results of the hypothesis testing above, it is evident that the Debt-to-Equity ratio (DER) has a positive effect on stock prices, meaning that if conditions remain, then any increase in DER will affect the increase in stock prices, on the other hand, if DER decreases, it will affect the decline in stock prices. The higher the DER, the greater the risk faced, and investors will ask for a higher rate of return (Sartono, 2010). This research is supported by previous research by Kusumawardani (2009) with the results of the research that the Debtto-Equity ratio (DER) has a positive effect on stock prices, Itabilah (2009) with the results of the study the Debt-to-Equity ratio (DER) has an effect on stock prices.

Based on the results of the hypothesis testing above, it is proven that Return on Assets has a positive effect on stock prices, meaning that if conditions are constant, any increase in ROA will affect an increase in stock prices, on the other hand, if ROA decreases, it will affect the decline in stock prices. This research is supported by previous research by Lambey (2008) with the results of the ROA and TATO research which have a significant effect on stock prices, Zuarni (2008) with the results of the ROA research having an effect on stock prices.

Based on the test results above, it is evident that PER, DER, and ROA simultaneously have a significant effect on stock prices. That is, if the PER, DER, and ROA increase, it indicates that the company has a high growth rate accompanied by a high level of ability to repay debts to other parties and is increasingly effective in utilizing assets to generate net profit after tax. This 
research is supported by research by Pratama (2009) which states that simultaneously all financial ratios (DER, PBV, EPS, DPR, PER, ROA have an effect on stock prices).

\section{CONCLUSION}

PER (price earning ratio), Debt to Equity Ratio (DER), and Return on Assets (ROA) have a positive partial effect on the stock price of manufacturing companies in the textile industry sub-sector for the period 2005-2012. PER (price to earning ratio), Debt to Equity Ratio (DER), and Return on Assets (ROA) simultaneously influence the stock price of manufacturing companies in the textile industry subsector for the period 2005-2012.

\section{REFERENCES}

Aikaeli, J., 2008. Commercial Banks Efficiency in Tanzania. Bank of Tanzania Monetary and Financial Affairs Department. A Paper Presented in a CSAE Conference on "Economic Development in Africa".

Angrawit, K., 2009. Analisis Pengaruh EPS, PER, ROE, FL, DER, ROA pada Harga Saham dan Dampaknya Terhadap Kinerja Perusahaan LQ45 yang Terdaftar di BEl periode 2005-2009.

Athanasius, T. 2012. Panduan Berinvestasi Saham. Jakarta: Media Computindo.

Claessens, S. and Hore, N. 2012. Foreign Banks: Trends, Impact and Financial Stability. IMF Working Paper, Research Department.

Darmadji, T and Fakhrudin. 2012. Pasar Modal di Indonesia. Edisi Ketiga. Jakarta: Salemba Empat.

Deitiana, T., 2014. Pengaruh Rasio Keuangan, Pertumbuhan Penjualan dan Deviden Terhadap Harga Saham.

Duncan, E. and Elliott, G. 2004. Efficiency, customer service and financial performance among Australian financial institutions. International Journal of Bank Marketing, 22(5), 319-342.

Fahmi, I. 2012. Pengantar Pasar Modal. Edisi Pertama. Bandung: Alfabeta.

Fullerton, R.R. and Wempe, W.F. 2009. Lean manufacturing, non-financial performance measures, and financial performance. International Journal of Operations \& Production Management, 29(3), 214-240.

Pratama, G.D.P., 2009. Pengaruh PBV, DER, EPS, DPR, dan ROA Terhadap Harga Saham (Studi Empiris pada Perusahaan Food and Beverage yang Terdaftar di BEI.

Ghozali, I., 2011. Aplikasi Analisis Multivariat Dengan Program IBM SPSS 19. Semarang: Badan Penerbit Universitas Diponegoro.

Hartono, J. 2010. Teori Portofolio dan Analisis Investasi. Edisi Ketujuh. Yogyakarta: BPFE.

Han W.P. and Sri Darma, G., 2018. Good Corporate Governance, Job Motivation, Organization Culture Which Impact Company Financial Performance. Jurnal Manajemen Bisnis, 15(3), 82-99. 
Hendratno, S.A., 2019. Pengaruh Current Ratio, Debt to Asset Ratio, Debt to Equity Ratio, Return on Asset dan Price Earning Ratio Terhadap Harga Saham Pada Perusahaan Sub-Sektor Plastik dan Kemasan Yang Terdaftar Di Bursa Efek Indonesia (BEI) Tahun 2012-2016. e-Proceeding of Management, 6(1), 303.

Itabilah, E.A., 2013. Pengaruh CR, QR, NPM, ROA, EPS, DER, dan PBV terhadap Harga Saham Perusahaan Property dan Real Estate yang Terdaftar di Bursa Efek Indonesia (BEI).

Jecheche, P., 2012. Devidend Policy and Stock Price Volatility: a case of the Zimbabwe Stock Exchange.

Khan, K.I., Effect of divident on stock price. Proceedings of 2nd International Conference on Business Management (ISBN: 978-969-9368-06-6). University of Central Punjab, Lahore, Pakistan.

Khan, K.I, Aamir M., Qayyum, A., Nasir A. and Khan, M.I., 2011. Can Dividend Decisions Affect the Stock Prices? A cash of Dividend Paying Companies of KSE. International Research Journal of Finance and Economics. ISSN 1450-2887 Issue 76 (2011). University of Central Punjab, Lahore, Pakistan.

Kamaludin and Indriani, 2012. Manajemen Keuangan. Edisi Revisi. Bandung: CV. Mandar Maju.

Kumaraswamy, S., 2016. Impact of working capital on financial performance of gulf coorporation council firms. International Journal of Economics and Financial Issues, 6(3), 1136-1142, ISSN:2146-4138, available at http: www.ecojournals.com.

Lambey, R. 2013. Analisis Pengaruh Rasio Keuangan Terhadap Harga Saham pada Bank di BEl.

Lukman, S., 2011. Manajemen Keuangan Perusahaan. Jakarta: Raja Grafindo Persada.

Maditinos, D., Chatzoudes, D., Tsairidis, C. and Theriou, G., 2011. The impact of intellectual capital on firms' market value and financial performance. Journal of Intellectual Capital, Vol. 12 No. 1, pp. 132-151.

Martalena dan Malinda, 2011. Pengantar Pasar Modal. Edisi Pertama. Yogyakarta: Andi.

Molina-Azorín, J.F., Claver-Cortés, E., López-Gamero, M.D. and Tarí, J.J. 2009. Green management and financial performance: a literature review. Management Decision, Vol. 47 No. 7, pp. 1080-1100.

Mosavi, S., Nekoueizadeh, S. \& Ghaedi, M. 2012. A study of relations between intellectual capital components, market value and finance performance, African Journal of Business Management. 6(4), 1396-1403.

Najjar, O. K., 2008. Financial Analysis for Bank of Palestine \& Jordan Ahli Bank (CAMEL Analysis). Retrieved from http://ssrn.com/abstract=1329588

Novasari, E. 2013. Pengaruh PER, EPS, ROA dan DER Terhadap Harga Saham Perusahaan Sub-Sektor Industri Textile Yang Go Public Di Bursa Efek Indonesia (BEI) Tahun 2009-2011.

Nwakaego, D.A., Ikechukwu, O.I., 2016. Management of Accounts Payable on the Financial Performance of Industrial/Domestic Manufacturing Companies in 
Nigeria. Journal of Humanities and Social Science, Vol.21, No.7, ISSN: 22790837.

Nyabuti, W.M., Benedict, A.O., 2014. The relationship between working capital management policy and financial performance of companies quotes at Nairobi securities exchange, Kenya. International Journal of Economics, Finance, and Management Sciences. 2(3): 212-219, doi: 110.11648/j.jjefm.20140203.12.

Parameswaran G, Meyer, M., Amara, L.A.N., Stanley, H.E., 2008. Inverse Cubic Law for The Distribution of Stock Price.

Pasaribu, R.B.F. 2008. Pengaruh Variabel Fundamental terhadap Harga Saham Perusahaan Manufaktur Go Public di Bursa Efek Indonesia periode 2003-2006.

Riyanto, B. 2010. Dasar-dasar Pembelanjaan Perusahaan. Yogyakarta: BPFE.

Safitri, A.L., 2013. Pengaruh Earning Per Share, Price Earning Ratio, Return on Asset, Debt to Equity Ratio dan Market Value Added Terhadap Harga Saham Dalam Kelompok Jakarta Islamic Index Tahun 2008-2011.

Said, R.M., Mohd, H.T. 2011. Performance and Financial Ratios of Commercial Banks in Malaysia and China.

Sartono, A., 2010. Manajemen Keuangan (Teori dan Aplikasi). Edisi keempat. Yogyakarta: BPFE.

Sondakh, F., Tommy, P. and Mangantar, M., 2015. Current Ratio, Debt to Equity Ratio, Return on Asset, Return on Equity Pengaruhnya Terhadap Harga Saham Pada Indeks LQ45 di BEI Periode 2010-2014. Jurnal EMBA, 3(2), 749-756.

Sugiyono. 2010. Metode Penelitian Kuantitatif Kualitatif dan R\&D. Bandung: Alfabeta.

Sunariyah, 2011. Pengantar Pengetahuan Pasar Modal Edisi Keenam. Yogyakarta: UPP STIM YKPN.

Tandelilin, E., 2010. Portofolio dan Investasi. Edisi Pertama. Yogyakarta: Kanisius. Watung, R.W, Ilat, V., 2016. Pengaruh Return on Asset (ROA), Net Profit Margin (NPM), dan Earning Per Share (EPS) Terhadap Harga Saham Pada Perusahaan Perbankan Di Bursa Efek Indonesia Periode 2011-2015. Jurnal EMBA Vol.4 No.2 Juni 2016, Hal. 518-529.

Zuliarni, S., 2012. Pengaruh Kinerja Keuangan Terhadap Harga Saham pada Perusahaan Mining and Mining Service di BEl. 